\title{
Paired Industrial Role in the Implementation of Dual System Education to Shape the Work Adaptability of Vocational High School Students in Greater Malang
}

\author{
Mohammad Maskan ${ }^{1}$, H.B. Suparlan², Alifiulahtin Utaminingsih ${ }^{3}$, Ludfi Djajanto ${ }^{4}$ \\ ${ }^{1,4}$ Malang State Polytechnic, East Java Indonesia \\ (alifmaskan@gmail.com) \\ ${ }^{2}$ Widyaisawaof Malang Teacher Development and Training Department, East Java Indonesia \\ ${ }^{3}$ Faculty of Social \& Politics Science of Brawiajaya University, East Java Indonesia
}

\begin{abstract}
Vocational high school emphasizes on the preparation of students into employment and the development of their professional attitude. This study focused on(1) the role of paired school-industrial cooperation under the dual system program and its influence to construct vocational student's work adaptability, (2) influence of student's individual characteristic on student's work adaptability. This research used the survey method with the quantitative analysis approach, with Structural Equation Modeling (SEM) analy sis. The sample of this research was 202 vocational high school students in Greater Malang. The findings show that (1) the role of paired industrial influence positively and significantly on the dual education system is 0.544 , (2) the role of paired industrial, dual education system and individual characteristic of vocational high student influence on the work adaptability of vocational high school students positively and significantly with the loading factor of $0.202 ; 0.318$ and 0.333 respectively. It is recommended that (1) theoretically, the formulation of government's policy on the practice in industry of the district autonomy era, should be based on the education policy reform, decentralization and good governance reviewed based on the act and regulation of education ministry. (2) Practically, there should be an increase between the industry and senior vocational school about communication, evaluation, link \& match, regulation and quality control on doing student practice in industry. Besides, there is a need to develop a further related research with a qualitative approach about the role of industrial paired and evaluation strategy toward dual system education implementationin order to develop the program effectively and efficiently in the future.
\end{abstract}

Keywords: Dual System Education, Paired Industrial Role, Individual Characteristic and Student Work Adaptability.

\section{Introduction}

\subsection{Background}

Vocational high schools in Indonesia are directed to the goals of preparing students to be ready as workers and developing their professional attitude. To reach the goals, dual system education has been established as a public policy in the form of professional skill education. This is implemented by combining education program in vocational high school and skill mastery program from the job training as the implementation of dual system education systematically and synchronously.
Work adaptability is the skill to adapt to the work environment for students of senior vocational high school who join dual education program. Ideally, students of vocational high school have high level of work adaptability which is implemented in their speed of adaptation in the work environment as a result of the educational process, in particularly as a sign of dual system education program at school. But we need to check the reality whether that goal has been reached, and we should analyze further. Paired institutions or industries play active role in the implementation of dual education program, 
especially in delivering practical training to the students of vocational high school who have various characteristics.

In line with that, Samani (2000) stated that education world should be more active in implementing link and match program with industry because of the high advance of technology development in industry. For that purpose, the Decree of Ministry of Education and Culture No. 323/U/1997 about the Administration of Dual System Education in vocational high school in which the education is conducted through dual system education, by doing job training in industries or government institutions. Hence, the implementation of dual system education policy is oriented more to the cooperative mechanism between schools in one side, and industries in other side, as an effort to anticipate the problems of external relevance with education.

\subsection{Research Problems}

Research problems are (1) the role of paired industries to the implementation of dual system education, (2) the role of paired industries to the work adaptability vocational high school students, (3) the role of characteristics of vocational high school students to the work adaptability, and (4) dual education system implementation to the forming of vocational high school students work adaptability.

\subsection{The Objectives of the Study}

In order to identify the influences of: (1) the role of paired industries to the implementation of dual system education, (2) the role of paired industries to the work adaptability vocational high school students, (3) characteristics of vocational high school students to the work adaptability, and (4) dual education system implementation to the forming of vocational high school students work adaptability.

\section{Review of Literature}

\subsection{Theoretical Analysis}

\subsubsection{Dual System Education Policy}

The objectives of dual system education are: (1) producing high quality workers who have levels of knowledge, skills and ethos needed by the industry, (2) gaining correlation and equivalence between vocational high schools and industries, (3) improving the effectiveness and efficiency of educational process and qualified workers training, and (4) giving recognition and appreciation to working experiences as a part of educational process.

\subsubsection{The Role of Paired Industries in Dual} Education Program

The results of study by Prater and Sileo (2002) stated that there are some good partnership, whether formal or nonformal ones as synthesized as follows: (1) formal partnership often involves students and teachers in the process of giving lessons needed in industries, (2) non formal partnership for new students in order to improve the their understanding by consulting the teachers informally, (3) partnership formality between industries with schools.

\subsubsection{Individual Characteristics (Students)}

Each individual has different goals, vision, needs, desires, and skills. These differences will be brought in the workplace, and in turn will result in different level of satisfaction, although they work in the same workplace. Gibson in Gani (2006) classified individual variables into three: (1) physical and mental ability and skill, (2) demography such as: gender, age and race and (3) background such as: family, social class and experience. 


\subsubsection{Students' Work Adaptability}

Work adaptability is a level of ability to adapt to industry. KurtLewin in Schevaletta M. (2000) stated that social adaptability is expressed mathematically as $B=f(P, E)$, which means independent behavior (B) as a results of interaction between individual (P) and environment $(\mathrm{E})$.

\subsection{Research Hypotheses}

Based on the research problems, the research hypotheses are as the following:

H1. There is a positive and significant influence of paired industries to the implementation of dual system education in Greater Malang (Malang Raya).

$\mathrm{H} 2$. There is a positive and significant influence of paired industries to the work adaptability of vocational high school students in Greater Malang.

H3. There is a positive and significant influence of students of vocational high schools to the students' work adaptability.

H4. There is a positive and significant influence of dual system education implementation to the work adaptability of vocational high school students in Greater Malang.

\section{Methodology}

\subsection{Research Design}

The research design used is survey with quantitative research design.

\subsection{Population and Sample}

The population of the research was all second grade students of public and private vocational high schools in the area of Greater Malang in academic year of 2009/2010 who conducted dual system education. Sample size was determined using proportional random sampling technique are 202 students in Malang city, Malang regency and Batu city.

\subsection{Data Collection}

This research needs two types of data, primary and secondary data. The techniques used for data collection were: questionnaire, interview, observation, and documentation.

\subsection{Research Instrument}

a) The implementation of Dual System Education consistsof the following dimensions:dual system education goals, dual system education materials, dual system education method, and dual system education evaluation.

b) Work adaptability of vocational high school students which consists of the following dimensions: organization awareness, communication capability, cooperation ability, innovative mindset, and working competence improvement.

c) The role of paired institutions which consist of the following dimension: the commitment between paired industries and schools, the relevance of dual system education materials, the efficiency of students' learning experience, the efforts to improve students' competence and the evaluation of dual system education implementation.

d) Students' characteristics which consist of the following dimensions: students' attitude, aspiration, perception, motivation, and students' social status.

\subsection{Data Analysis}

Based on the above paradigm, the data analysis in this research used Structural Equation Modeling (SEM). 


\section{Result and Discussion}

\subsection{Respondent Description}

The number of instruments had been filled by respondents and given back to the researcher is as follows: from 202 instruments given to respondents, only 2 respondents did not give back instruments so the number of respondents used as data in this research is 200 students. Based on the gender, the sample consists of: 114 male students (57\%) and 86 female students (43\%); and education programs consist of: Accounting 27 students (13.5\%), Secretary 26 students (13\%), Office Administration 18 students
(9\%), Selling 15 students (7.5\%), Seedling 15 students (7.5\%), Hotel 20 students (10\%), Automotive Engineering 24 students (12\%), Electronic Engineering 18 students (9\%), Electrical Engineering 16 students (8\%), Civil Engineering 11 students (5.5\%), and Industrial Engineering 10 students (5\%).

4.2. Structural Model of Research Results and Hypothesis Test

The explanation of the influence of endogenous variables to the exogenous variables and the hypothesis test is presented in the following Table 1.

Table 1. Loading Factor Coefficient of SEM and Hypothesis Test

\begin{tabular}{|c|c|c|c|c|c|c|c|}
\hline \multicolumn{3}{|c|}{ Correlation } & Estimate & S.E. & C.R. & $\mathbf{P}$ & Description \\
\hline $\begin{array}{l}\text { DualSystemEducation } \\
\left(\mathrm{X}_{\mathrm{A}}\right) \\
\text { the work adaptability } \\
\text { of vocational high } \\
\text { school students (Y) } \\
\text { the work adaptability } \\
\text { of vocational high } \\
\text { school students (Y) } \\
\text { the work adaptability } \\
\text { of vocational high } \\
\text { school students (Y) }\end{array}$ & $\leftarrow$ & $\begin{array}{l}\text { Industrial } \\
\text { Role }\left(\mathrm{X}_{\mathrm{B}}\right) \\
\text { DualSystemE } \\
\text { ducation }\left(\mathrm{X}_{\mathrm{A}}\right) \\
\text { IndustrialRole } \\
\left(\mathrm{X}_{\mathrm{B}}\right) \\
\text { Students } \\
\text { Individual } \\
\text { Characteristic } \\
\mathrm{S} \\
\text { (XC) }\end{array}$ & 0.333 & 0.098 & 3.405 & 0.000 & $\begin{array}{l}\text { Hypothesis } 1 \\
\text { is accepted } \\
\text { Hypothesis } 2 \\
\text { is accepted } \\
\text { Hypothesis } 3 \\
\text { is accepted } \\
\text { Hypothesis } 4 \\
\text { is accepted }\end{array}$ \\
\hline
\end{tabular}

Resource: primary data 


\subsection{Discussion}

This study has found a model that is in line with the empirical facts. Afterward, empirical model found from the research is also relevant as a foundation for analyzing the quality improvement of dual system education implementation for students, teachers, schools and paired industries. Therefore, according to Anwar (2002) schools need to prepare in giving practical skills before the implementation of dual system education through the cooperation between schools and paired industries so the skills taught were relevant to the need of industries.

Meanwhile, the influence of paired industries in improving work adaptability can be described as follows: that before the implementation of dual system education, the industries have collecting data related to students' skills. It supports the study by Timothy (2001) that industries had a big role in the success of the implementation of dual system education.

That also explains why students' characteristics can improve the students' work adaptability. It is because the placement of students for job training in the implementation of dual system education is based on the characteristics of each student. We can also refer to the results of the study by Schiopeppers and Patriana in Yunus (2006) that students need to be equipped with theoretical knowledge and practical knowledge, as well as attitude and behavior before entering the employment world, whether as workers or self employerto become responsible citizens.

\section{Conclusion and Recommendation}

\subsection{Conclusion}

Based on the description in Section IV, the following statements can be inferred: a. Accepting the hypothesis that there is a positive and significant influence of paired industries to the implementation of dual system education in Greater Malang area.

b. Accepting the hypothesis that there is a positive and significant influence of paired industries to the work adaptability of vocational high school students in Greater Malang area.

c. Accepting the hypothesis that there is a positive and significant influence of students of vocational high school students' characteristics to the students' work adaptability.

d. Accepting the hypothesis that there is a positive and significant infleunce of the implementation of dual system education to the students' work adaptability.

\subsection{Recommendation}

\subsubsection{Theoretical Recommendation}

To support the program of Malang City as a Vocational City, the formulation of dual system education policy should be based on the educational policy reform, decentralization and good governance.

\subsubsection{Practical Recommendation}

1) The quantity and quality of communication between vocational high school and paired industries should be improved for the implementation of dual system education, especially in designing dual system education implementation which refers to link and match policy and working regulations.

2) The designing of dual system education program and evaluation by vocational high schools together with paired industries; increased frequency of visit by academic advisor teacher from the school in guiding the students which is efficient and effective in monitoring the implementation of dual system education by related institutions. 


\section{References}

(1) Anwar. (2002).Pelaksanaan Program Pendidikan Sistem Ganda pada SMK di Kota Kendari.Jurnal Pendidikan dan Kebudayaan. 36, 13 - 17.

(2) Anwar. (2004).Life Skills Education (Pendidikan Kecakapan Hidup). Bandung: PenerbitAlfabeta.

(3) Depdiknas. (1997).Keputusan Mendikbud RI Nomor 323/U/1997 tentang Penyelenggaraan PSG pada SMK. Jakarta: Departemen Pendidikan dan Kebudayaan.

(4) Gani S, Mursalim Umar. (2006). Pengaruh Karakteristik Individu, Karakteristik Pekerjaan, Karakteristik Organisasi, Motivasi Kerja, Imbalandan Kinerja Terhadap Kepuasan Kerja Karyawan. Disertasi, Program Studi Ilmu Ekonomi, Program Pascasarjana, Universitas Brawijaya, Malang.

(5) Prater, Anne, Mary \& W. Sileo, Thomas,. (2002). School-University Partnership in Special Education Field Experience.Remedial and Special Education, Nov/Dec 2002; 23, 6 Wilson Education Abstract.

(6) Samani.(2000).RevitalisasiSekolahMenengahKeju ruan, Makalah Disampaikan pada Diskusi di PusatPenelitianKebijakanBalitbangDepdiknas, Jakarta: Depdiknas.

(7) Schevaletta, M. (2000). A Questionnaire Study of The College Social Adjustment of Block Student from : Power Socio Economic. Journal of Counselling Psychology. 28 (2), 240 - 255.

(8) Timothy, J.S. (2001).Public/Private Pertnership in Education. Dissertation Submitted to The Division of Research and Advanced Studies of The University of Cincinnati.

(9) Yunus, Muhammad (2006,).Kebijakan Kemitraan Pendidikan Kejujuran; Analisis Implementasi
Kebijakan Praktek Industri dalam Rangka Peningkatan Mutu dan Relevansi Lulusan SMK di Kota Tarakan Propinsi Kalimantan Timur.Disertasi, Program Doktorllmu Administrasi, Fakultas Ilmu dministrasi Universitas Brawijaya, Malang. 